\title{
Relationships of Preharvest Weather Conditions and Soil Factors to Susceptibility of Sweetpotato to Postharvest Decay Caused by Rhizopus stolonifer and Dickeya dadantii
}

Brooke A. Edmunds, Department of Horticulture, Oregon State University, and Linn County Extension Office, Albany, OR 97321; Christopher A. Clark, Department of Plant Pathology \& Crop Physiology, Louisiana State University Agricultural Center, Baton Rouge 70803; Arthur Q. Villordon, Sweet Potato Research Station, Louisiana State University Agricultural Center, Chase 71324; and Gerald J. Holmes, Strawberry Sustainability Research \& Education Center, Cal Poly San Luis Obispo, College of Agriculture, Food \& Environmental Science, San Luis Obispo, CA 93407-0250

\begin{abstract}
Edmunds, B. A., Clark, C. A., Villordon, A. Q., and Holmes, G. J. 2015. Relationships of preharvest weather conditions and soil factors to susceptibility of sweetpotato to postharvest decay caused by Rhizopus stolonifer and Dickeya dadantii. Plant Dis. 99:848-857.

Postharvest soft rots of sweetpotato caused by Rhizopus stolonifer (Rhizopus soft rot) and Dickeya dadantii (bacterial root rot) occur sporadically and can result in significant losses. A 3-year field study related preharvest conditions, including soil texture, chemistry, and fertility; air temperature; soil temperature and moisture; and various cultural practices (153 total variables), to postharvest susceptibility to both diseases in 75 sweetpotato fields in North Carolina and 63 sweetpotato fields in Louisiana. Storage roots were sampled from each field, cured, stored, and inoculated with each pathogen after 100 to 120 days in storage. Disease susceptibility was measured as incidence of diseased storage roots 10 days following inoculation. There was wide variation from field to field in incidence of both diseases ( 0 to $100 \%$ for Rhizopus soft rot and 5 to $95 \%$ for bacterial root rot) in both states in each year. Correlations between disease incidence and each of the preharvest variables revealed numerous significant correlations but the variables that correlated with disease incidence were different between North Carolina and Louisiana. Models for both diseases were built by first using forward

stepwise regression to identify variables of interest, followed by a mixedmodel analysis to produce a final reduced model. For North Carolina fields, postharvest Rhizopus soft rot susceptibility was described by the percentage of the soil cation exchange capacity occupied by calcium, amount of plant-available soil phosphorus, percent soil humic matter, mean air temperature, mean volumetric soil moisture at $40 \mathrm{~cm}$ in depth, and mean soil temperature at $2 \mathrm{~cm}$ in depth. Postharvest bacterial soft rot susceptibility was described by soil $\mathrm{pH}$ and the number of days of high soil temperature late in the season. For Louisiana fields, Rhizopus soft rot susceptibility was described by a complex of variables, including late-season air and soil temperature and late-season days of extreme soil moisture. For bacterial root rot, days of low air temperature and days of high soil temperature late in the season as well as days of low soil moisture best described variation. Although the influence of preharvest variables on postharvest susceptibility was profound for each disease, the complexity of factors involved and differences between the data for the two states makes development of a predictive system extremely difficult.
\end{abstract}

Sweetpotato (Ipomoea batatas Lam.) production worldwide was 110 million metric tons in 2013, with most production in China (FAO 2014). In the United States, sweetpotato is an important commodity, with North Carolina producing approximately 37 and $47 \%$ and Louisiana about 20 and $7 \%$ of the U.S. crop in 2003 at the outset of this study and in 2013, respectively (United States Department of Agriculture 2014). Postharvest diseases are a constant threat and are especially costly because all expenditures associated with growing, harvesting, and storage have already been incurred by the producer. Postharvest diseases such as those caused by Fusarium oxysporum, F. solani, and Ceratocystis fimbriata develop slowly during longterm storage. Other postharvest diseases, such as Rhizopus soft rot and bacterial root rot, develop very rapidly during transit to market and are of great concern due to the amount and timing of losses, with the potential for rejection of large shipments.

Rhizopus soft rot, caused by the fungus Rhizopus stolonifer (syn. $R$. nigricans), is the most common postharvest disease of sweetpotato (Clark et al. 2013). It causes a watery, soft rot that can result in severe yet sporadic losses. R. stolonifer requires a wound for infection to occur (Lauritzen 1935; Srivastava and Walker 1959) and the injuries that occur during the packing process provide an infection court for Rhizopus soft rot development. For this reason, the majority of

Corresponding author: C. A. Clark; E-mail: cclark@agctr.lsu.edu

Accepted for publication 16 December 2014.

http://dx.doi.org/10.1094/PDIS-11-14-1143-RE

(C) 2015 The American Phytopathological Society sweetpotato packers use a prophylactic fungicide application against Rhizopus soft rot (Edmunds et al. 2008). Anecdotal evidence suggests that prophylactic fungicide applications may not be necessary because storage roots are often not susceptible to decay. Growers, packers, and university cooperators have observed that Rhizopus soft rot incidence varies among fields and among and between growing seasons. However, the source of this variability has not been confirmed with systematic studies.

Bacterial root rot, caused by Dickeya dadantii (syns. Pectobacterium chrysanthemi and Erwinia chrysanthemi), is a less common disease of sweetpotato and also occurs sporadically (Clark et al. 2013; Schaad and Brenner 1977). The symptoms of postharvest bacterial root rot include a watery soft rot with or without a dark brown margin surrounding the decayed area. Although it is known that the bacterium can be present as latent populations inside the plants throughout the production cycle (Duarte and Clark 1992), little else is known about disease cycles on sweetpotato. Oxygen deprivation and exposure to high temperatures $\left(>30^{\circ} \mathrm{C}\right)$ are contributing factors to postharvest disease development. Thus, one management approach is to avoid these conditions during storage and transit to market.

The sporadic incidence of both diseases despite use of nearly identical postharvest environments (e.g., curing, storage, and packing) brings into question whether there are locally specific events or conditions occurring preharvest that affect postharvest susceptibility. A comprehensive strategy for management of these diseases requires identification of the factors which are related to variations in disease susceptibility. The objectives of this study were to (i) determine whether field-to-field variability exists in disease susceptibility within and among growing seasons, (iii) determine whether the effect of preharvest variables on susceptibility to Rhizopus soft rot and bacterial root rot is related, and (iii) identify the predisposing 
preharvest environmental conditions and agronomic practices that correlate to postharvest susceptibility of sweetpotato to both diseases.

\section{Materials and Methods}

Sweetpotato storage roots ('Beauregard') were collected from 75 fields under commercial production in North Carolina (32 fields in 2004, 27 in 2005, and 16 in 2006) and 63 fields in Louisiana (20 in 2004, 21 in 2005, and 22 in 2006). The reduction in field sites for 2006 in North Carolina is due to a change in cultivar (i.e., 'Covington'), which has slightly different reactions to the soft rot diseases, that occurred in the other fields. New field locations were selected each year of the study (i.e., field locations were not repeated) in North Carolina but, in Louisiana, 10 fields used in 2004 were sampled again in 2005 and 14 fields sampled in 2006 were used in either 2004 or 2005 . Fields were selected primarily based on growers' willingness to provide them for this study. Within each commercial field, 8 to 32 rows were designated as the experimental area. The length of the rows varied with individual fields but was at least $30 \mathrm{~m}$. Within this area, the experimental design was a split plot with two replications that compared insecticide-treated beds ( 8 to 16 rows) with noninsecticide-treated beds ( 8 to 16 rows). The specific insecticides and number of applications were selected at the discretion of the individual growers. Other than the insecticide treatment, the experimental area was treated the same as the rest of the field, using routine practices of the individual grower.

Harvest dates were determined by the grower based on storage root size and weather conditions. At harvest, a single-row plow was used to turn soil and bring storage roots to the surface in North Carolina whereas, in Louisiana, storage roots were dug by hand using potato forks. One row in the middle of each split plot treatment was sampled. Within this row, two 9.2-m plots were marked out for each replicate and 50 U.S. number 1 grade storage roots $(7.6$ to $22.9 \mathrm{~cm}$ length, 4.5 to $8.9 \mathrm{~cm}$ diameter, $<567 \mathrm{~g}$ maximum weight) were collected from within the plot. On the day of harvest, storage roots were placed into ventilated plastic crates and transported to a storage facility, where they were cured at $29^{\circ} \mathrm{C}$ for 5 days and stored at 15 to $18^{\circ} \mathrm{C}$ until inoculation at 100 to 120 days after harvest, the storage period Holmes and Stange (2002) determined to be the peak for susceptibility of Beauregard to Rhizopus soft rot.

Environmental factors. Hourly weather data for the growing season were modeled for each field site using the SkyBit service (ZedX, Inc., Bellefonte, PA). The set of weather parameters estimated by SkyBit included air temperature, soil temperature (at depths of 2 and $4 \mathrm{~cm}$ ), and soil moisture (at depths of 10, 40, and $100 \mathrm{~cm}$ ) (Table 1). For Louisiana, weather stations also were installed in one field on each farm. The weather stations included a data logger (Watchdog 425; Spectrum Technologies, Inc., Plainfield, IL) with an internal recorder for air temperature that was placed inside a radiation shield (Spectrum Technologies Model 3363 ) affixed at $1.22 \mathrm{~m}$ above ground level to a $2.54 \mathrm{~cm}$-diameter PVC pole. A tipping bucket rain collector (Spectrum Technologies Model 3665R), a Watermark soil moisture sensor (Spectrum Technologies Model 6450WD20), and a soil temperature sensor (Spectrum Technologies Model 3667-20) were connected to the external ports of the data logger. The soil temperature and moisture sensors were buried in the sweetpotato row at a depth of $15 \mathrm{~cm}$ and the data logger was programmed to record readings every $2 \mathrm{~h}$. To allow comparisons between the two states, the SkyBit weather data were used for both states in this study. The hourly or bihourly data were averaged into daily means and used to calculate growing season averages and averages for the 4 weeks prior to harvest $(7,14,21$, and 28 days preharvest) for each field. Threshold variables were calculated from the estimated weather data and included low air temperature, high and low soil temperature (at depths of 2 and $4 \mathrm{~cm}$ ), and high and low soil moisture (at depths of 10, 40, and $100 \mathrm{~cm})($ Table 1). A threshold was considered crossed if the variable's defined limits were exceeded for at least $1 \mathrm{~h}$ in a 24-h period. For example, if soil temperature dropped below $13{ }^{\circ} \mathrm{C}$ for any single hour in a day (01:00 to 24:00), that day was considered to be a "low soil temperature" day. The threshold definitions are based on preliminary research that defines environmental stress as related to sweetpotato growth and yield (Villordon et al. 2009). Differentials between temperature and moisture at soil depths of 10,40 , and $100 \mathrm{~cm}$ also were calculated.
Agronomic factors. Composite soil samples were collected at harvest in each field. Soil samples were collected using a $1.9-\mathrm{cm}-$ diameter soil probe to a depth of $16 \mathrm{~cm}$ following a zig-zag pattern across the experimental area (one composite sample comprised 50 soil plugs/field). Soil nutrients were quantified using the Mehlich 3 extraction method (Mehlich 1984) by Waters Agricultural Laboratories Inc., Camilla, GA and reported in the North Carolina Department of Agriculture Index (Hardy et al. 2008). Levels of organic matter and soil texture (i.e., percent sand, silt, and clay) were also determined.

Grower interviews were conducted to identify the previously planted crop ( 1 year prior) for each field. Weed density was estimated immediately prior to harvest by weed scientists in North Carolina. Damage to storage roots caused by root-feeding insects (including white grubs and flea beetles) was determined by entomologists by visual examination of harvested storage roots obtained from the same field locations

Postharvest disease assessment. Storage roots were evaluated for susceptibility to Rhizopus soft rot and bacterial root rot after 100 to 120 days in storage at 15 to $18^{\circ} \mathrm{C}$. The day before inoculation, storage roots were hand washed in tap water and allowed to air dry. Each replication (50 storage roots) was separated into two sets of 20 storage

Table 1. Potential variables of Rhizopus soft rot and bacterial root rot incidence recorded for each sweetpotato field location in Louisiana and North Carolina, 2004 to 2006

\begin{tabular}{|c|c|}
\hline Variable name & Description \\
\hline \multicolumn{2}{|l|}{ Soil $^{\mathrm{a}}$} \\
\hline Sand & Sand $(\%)$ \\
\hline Silt & Silt $(\%)$ \\
\hline Clay & Clay $(\%)$ \\
\hline Ac & Exchangeable acidity $\left(\mathrm{meq} / 100 \mathrm{~cm}^{3}\right)$ \\
\hline CEC & Cation exchange capacity $\left(\mathrm{meq} / 100 \mathrm{~cm}^{3}\right)$ \\
\hline HM & Soil humic matter $(\%)$ \\
\hline $\mathrm{pH}$ & Soil pH \\
\hline $\mathrm{Ca}$ & $\begin{array}{l}\text { Percent of cation exchange capacity } \\
\text { occupied by calcium }(\%)\end{array}$ \\
\hline $\mathrm{Cu}$ & Plant available copper (index) \\
\hline $\mathrm{K}$ & Plant available potassium (index) \\
\hline $\mathrm{Mg}$ & $\begin{array}{l}\text { Percentage of CEC occupied by } \\
\text { magnesium }(\%)\end{array}$ \\
\hline $\mathrm{Mn}$ & Plant available manganese (index) \\
\hline $\mathrm{P}$ & Plant available phosphorus (index) \\
\hline $\mathrm{S}$ & Plant available sulfur (index) \\
\hline $\mathrm{Zn}$ & Plant available zinc (index) \\
\hline \multicolumn{2}{|l|}{ Weather ${ }^{b}$} \\
\hline AT & Air temperature $\left({ }^{\circ} \mathrm{C}\right)$ \\
\hline AT-L & Days of low air temperature $\left(<18^{\circ} \mathrm{C}\right)^{\mathrm{c}}$ \\
\hline $\mathrm{ST}_{2}, \mathrm{ST}_{4}$ & $\begin{array}{l}\text { Soil temperature }\left({ }^{\circ} \mathrm{C}\right) \text { estimated at } 2 \text { - and } \\
\text { 4-cm depths }\end{array}$ \\
\hline $\mathrm{ST}-\mathrm{H}_{2}, \mathrm{ST}-\mathrm{H}_{4}$ & $\begin{array}{l}\text { Days of high soil temperature }\left(>32^{\circ} \mathrm{C}\right) \\
\text { estimated at } 2-\text { and } 4-\mathrm{cm} \text { depths } \\
\text { c }\end{array}$ \\
\hline $\mathrm{ST}_{-} \mathrm{L}_{2}, \mathrm{ST}-\mathrm{L}_{4}$ & $\begin{array}{l}\text { Low soil temperature }\left(<13^{\circ} \mathrm{C}\right) \text { estimated } \\
\text { at } 2 \text { - and } 4-\mathrm{cm} \text { depths })^{\mathrm{c}}\end{array}$ \\
\hline $\mathrm{SM}_{10} \mathrm{SM}_{40}, \mathrm{SM}_{100}$ & $\begin{array}{l}\text { Soil moisture [volumetric water potential } \\
\left(\mathrm{m}^{3} / \mathrm{m}^{3}\right) \text { ] estimated at } 10-, 40-\text {, and } \\
100-\mathrm{cm} \text { depths }\end{array}$ \\
\hline $\mathrm{SM}-\mathrm{H}_{10} \mathrm{SM}-\mathrm{H}_{40}, \mathrm{SM}-\mathrm{H}_{100}$ & $\begin{array}{l}\text { Days of high soil moisture [volumetric } \\
\left.\text { water potential }>0.31\left(\mathrm{~m}^{3} / \mathrm{m}^{3}\right)\right] \text { estimated } \\
\text { at } 10-, 40-\text {, and } 100-\mathrm{cm} \mathrm{depths}^{\mathrm{c}}\end{array}$ \\
\hline SM-L 10, SM-L 40, SM-L ${ }_{100}$ & $\begin{array}{l}\text { Days of low soil moisture [volumetric } \\
\text { water potential }<0.15\left(\mathrm{~m}^{3} / \mathrm{m}^{3}\right) \text { ] estimated } \\
\text { at } 10-, 40-\text {, and } 100-\mathrm{cm} \mathrm{depths}^{\mathrm{c}}\end{array}$ \\
\hline
\end{tabular}

a Soil chemistry and fertility from soil sample taken at harvest was quantified using the North Carolina Department of Agriculture Index (Hardy et al. 2008).

b Estimated hourly weather data.

c A day was recorded as experiencing the variable when a single hour in the 24-h period reached or exceeded the defined threshold. Threshold definitions are based on preliminary research that defines environmental stress as related to sweetpotato growth and yield (Villordon et al. 2009). 
roots and one set of 10 storage roots. One 20-root set was inoculated with $R$. stolonifer, the other set of 20 storage roots was inoculated with $D$. dadantii, and, in North Carolina, another set of 10 storage roots was held at 15 to $18^{\circ} \mathrm{C}$ and served as a noninoculated control. Because incidence of disease is often very low (Edmunds and Holmes 2009) and variable under normal handling of sweetpotato, artificial inoculation techniques were used that, in previous studies, resulted in less variability and suitable incidence of disease to allow discrimination of genetic differences among cultivars in susceptibility and resistance to each disease (Clark and Hoy 1994; Clark et al. 1989; Edmunds and Holmes 2009; Holmes and Stange 2002).

The $R$. stolonifer isolate used in this study was originally collected in 1992 from a sweetpotato in Louisiana showing Rhizopus soft rot symptoms and signs and stored on silica crystals at $3^{\circ} \mathrm{C}$, according to the method described by Perkins (1962). To produce inoculum, silica crystals were transferred to potato dextrose agar (Difco, Sparks, MD) and incubated at room temperature $\left(21\right.$ to $\left.22^{\circ} \mathrm{C}\right)$ for 5 days. The plates were washed with a $0.01 \%$ octylphenol ethoxylate (Triton X-15; Dow, New Jersey) solution and the spores were removed by gently rubbing with a bent glass rod. The suspension was filtered through three layers of cheesecloth to remove mycelial fragments and adjusted to a concentration of $1 \times 10^{6}$ sporangiospores $/ \mathrm{ml}$. On the day of inoculation, storage roots were wounded on opposite sides of the midsection with an impact wound device which created a consistent wound ( $8 \mathrm{~mm}$ in diameter by $1 \mathrm{~mm}$ deep). The wounds were immediately painted with the spore suspension using a $24.5-\mathrm{cm}$-wide paintbrush. After inoculation, storage roots were placed into ventilated plastic storage crates and stored at 15 to $18^{\circ} \mathrm{C}$. At 10 days, storage roots were rated for incidence of partial or total decay by Rhizopus soft rot. Because the incidence of partial decay was very low relative to total decay and because the partially decayed roots generally had large volumes of root that had been decayed and the soft rot was still actively progressing, the sum of the incidence of partial and total decay was used for analyses.

The $D$. dadantii isolate used in this study was recovered in Louisiana in 1995 from a sweetpotato storage root showing bacterial root rot symptoms. The bacterium was stored on silica crystals at $-12^{\circ} \mathrm{C}$ until use. Two days prior to inoculation, the bacterium was revived
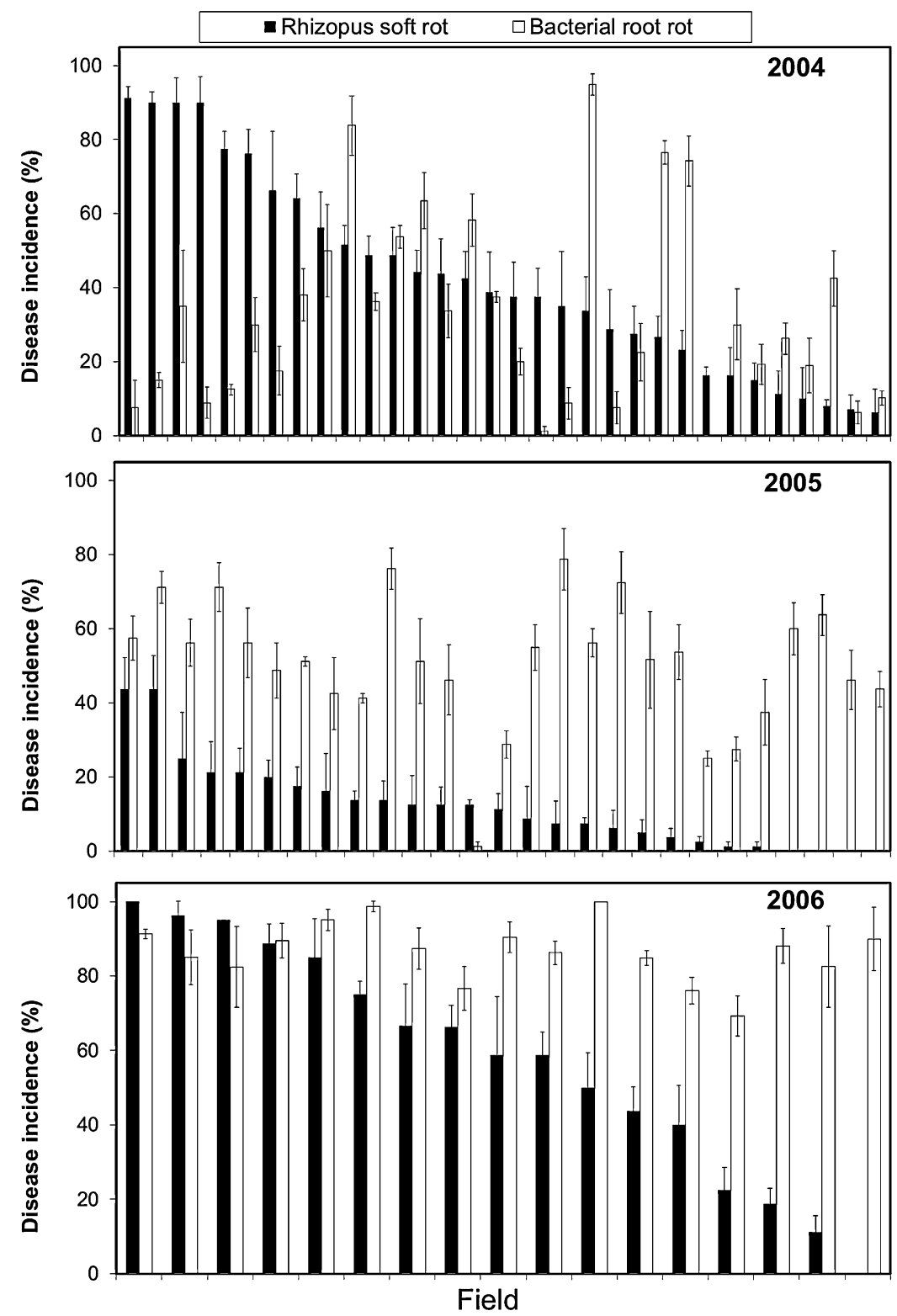

Fig. 1. Incidence of Rhizopus soft rot and bacterial root rot following artificial inoculation at 100 to 120 days after harvest with Rhizopus stolonifer and Dickeya dadantii, respectively, in North Carolina in 2004, 2005, and 2006. Each set of paired columns represents a single field and is sorted in descending order for Rhizopus soft rot incidence (left to right). Bars represent standard errors of the means. 
by plating the silica crystals onto yeast dextrose carbonate agar (YDCA) and incubating at $30^{\circ} \mathrm{C}$ for $24 \mathrm{~h}$. The resulting colony was streaked onto fresh YDCA and incubated at $30^{\circ} \mathrm{C}$ for $24 \mathrm{~h}$. On the day of inoculation, the plates were washed with sterile distilled water and the resulting suspension adjusted to $1 \times 10^{8} \mathrm{CFU} / \mathrm{ml}$ using a spectrophotometer $(0.1$ optical density at $620 \mathrm{~nm})$. The storage roots were inoculated by stabbing the midsection of each storage root with a micropipettor and disposable plastic tip containing $50 \mu \mathrm{l}$ of the bacterial suspension (the tip was left in place, approximately $1 \mathrm{~cm}$ deep into the tissue). The inoculated storage roots were placed into ventilated plastic crates and stored at $29^{\circ} \mathrm{C}$ for 10 days, after which they were rated for incidence of bacterial soft rot.

With both pathogens, disease incidence was easily assessed because large portions of storage root tissue were soft, centered at the point of inoculation, whereas sound storage roots remained firm, even at the point of inoculation.

Data analysis. Pearson correlation coefficients were calculated between incidence of each disease and all variables (Table 1) for the individual years of the study and all 3 years pooled (PROC CORR, SAS V8; SAS Institute, Cary, NC). Extreme outliers were removed from the dataset (replaced as missing data points) and disease data were averaged over replications within the two insecticideand the two noninsecticide-treated replications. An initial model was created using stepwise forward selection to identify important variables (PROC REG, SAS V8; SAS Institute) for bacterial root rot and Rhizopus soft rot susceptibility, with all fields set as random. Interactions were not included because of the large (153 total) number of potential variables in the data set. Only those models in which all variables were significant $(P$ value $<0.10)$ were kept for further analysis. Mixed-model analysis (PROC MIXED) with fields set as random was carried out between the variables identified in the stepwise selection as potentially important. Final reduced mixed models for each disease were obtained by eliminating variables one at a time if $P$ was $>0.05$.

\section{Results}

A wide range in susceptibility to Rhizopus soft rot and bacterial root rot was observed both among fields within a single year and among the years of this study (Figs. 1 and 2). Overall, the incidence of Rhizopus soft rot was the same in Louisiana and North Carolina
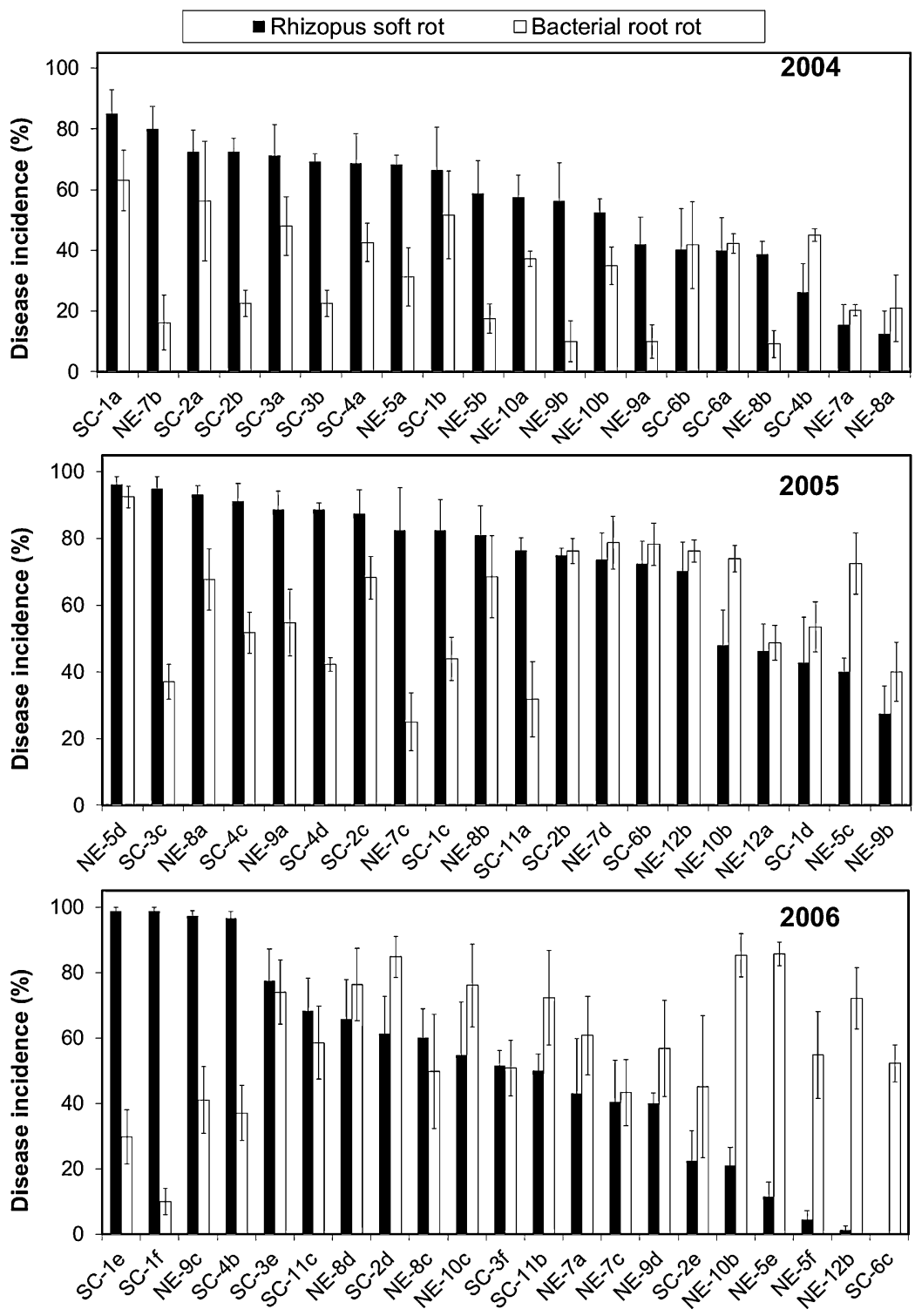

Field

Fig. 2. Incidence of Rhizopus soft rot and bacterial root rot following artificial inoculation at 100 to 120 days after harvest with Rhizopus stolonifer and Dickeya dadantii, respectively, in Louisiana in 2004, 2005, and 2006. Each set of paired columns represents a single field (identified in labels on the X axis) and is sorted in descending order for Rhizopus soft rot incidence (left to right). Bars represent standard errors of the means. 
but, in North Carolina in 2005, Rhizopus soft rot incidence was $12.2 \%$ (standard deviation $[\mathrm{SD}]=15.2$ ), and a significant decrease in Rhizopus soft rot incidence was seen across all fields as compared with $2004(42.5 \%, \mathrm{SD}=29.6)$ and $2006(57.1 \%, \mathrm{SD}=33.1)$. A significant increase occurred in Louisiana in $2005(73.0 \%, \mathrm{SD}=24.1)$ as compared with $2004(55.8 \%, \mathrm{SD}=24.7)$ and $2006(50.7 \%, \mathrm{SD}=$ 35.0). Mean bacterial root rot in North Carolina was $32.5 \%$ (SD = $27.4)$ in $2004,50.8 \%(S D=20.8)$ in 2005 , and $86.5 \%(S D=12.6)$ in 2006. Bacterial root rot was significantly lower in 2004 (32.8\%, $\mathrm{SD}=17.6)$ in Louisiana than in $2005(57.2 \%, \mathrm{SD}=20.0)$ or 2006 $(57.0 \%, \mathrm{SD}=22.0)$ and, for each field (except SC-4b) that was used in more than 1 year, the incidence varied by at least twofold between years (Fig. 2). In North Carolina, the incidence of Rhizopus soft rot (31.7 and $34.7 \%$ ) and bacterial root rot (51.4 and 52.3\%) did not differ significantly between the insecticide-treated and untreated strips, respectively. In Louisiana, the insecticide-treated strips had 53.0 and $57.7 \%$ incidence which was significantly different from the untreated strips, which had 47.2 and $61.7 \%$ incidence of bacterial root rot and Rhizopus soft rot, respectively, and for each field (except SC-2b) that was used in more than 1 year, the incidence varied by at least twofold between years (Fig. 2). For the 3-year pooled data set, mean Rhizopus soft rot incidence was 58 and $33 \%$ and mean bacterial root rot was 51 and 52\% for Louisiana and North Carolina, respectively.

A significant correlation $(r=0.018, P=0.04)$ was found in North Carolina between Rhizopus soft rot susceptibility and bacterial root rot susceptibility when the 3 years were pooled. A negative correlation was found in Louisiana $(r=-0.238, P=0.043)$.

Pearson correlations of bacterial root rot incidence and Rhizopus soft rot incidence with all variables revealed significant relationships only between soil and weather variables. There was no significant correlation between incidence of either disease with insect injury, weed density, or previous year's crop (data not shown) in the individual years of the study or the 3-year pooled dataset.

Within the soil fertility and chemistry variables, there were many significant correlations for incidence of both Rhizopus soft rot and bacterial root rot (Table 2). However, the variables that correlated with disease incidence differed between Louisiana and North Carolina, as did the mean values for these variables. For Rhizopus soft rot incidence in North Carolina, highly significant negative correlations were seen with percent potassium $(\mathrm{K})$ and highly significant positive correlations were seen with soil manganese and phosphorus (P) indices. For bacterial root rot incidence, highly significant negative correlations were seen with percent humic matter (HM) and soil $\mathrm{pH}$, and highly significant positive correlations were seen with soil acidity, cation exchange capacity (CEC), and copper $(\mathrm{Cu})$, sulfur $(\mathrm{S})$, and zinc (Zn) indices. Soil texture (percent sand, silt, or clay) did not significantly correlate to either disease. For Rhizopus soft rot in Louisiana, highly significant negative correlations were observed with soil $\mathrm{K}$ and $\mathrm{P}$ and a significant positive correlation was observed with percent HM. For bacterial root rot incidence, there was a highly significant positive correlation with percent sand, a highly significant negative correlation with percent silt, and a significant negative correlation with soil $\mathrm{Cu}$.

Within the weather variables, significant correlations were seen for both Rhizopus soft rot and bacterial root rot in both states (Tables 3, 4 , and 5). Both diseases showed significant negative correlations to increasing mean air temperature and soil temperature at depths of both 2 and $4 \mathrm{~cm}$ in all time periods $(7,14,21$, and 28 days preharvest and entire growing season) in North Carolina. However, in Louisiana, where mean air temperatures were 1.3 to $2.4^{\circ} \mathrm{C}$ warmer and mean soil temperatures were 1.3 to $2.6^{\circ} \mathrm{C}$ warmer than for North Carolina, there was no correlation with bacterial root rot and a highly significant positive correlation with Rhizopus soft rot (Table 3). Soil moisture levels at depths of 10,40 , and $100 \mathrm{~cm}$ in all time periods were significantly correlated in North Carolina for both diseases; however, Rhizopus soft rot susceptibility showed a positive correlation whereas bacterial root rot showed a negative correlation. Seasonlong soil moisture had a weak negative correlation with Rhizopus soft rot but otherwise there were no correlations with soil moisture in Louisiana. These correlations to weather variables were not seen when individual years were analyzed separately (data not shown). This is likely due to a smaller sample size, year-to-year variation in mean temperatures, and the strength of the correlation within an individual year.

Surpassing thresholds for high and low air and soil temperature were also significantly correlated to incidence of both diseases (Table 4). Increased days in which air temperature dropped below $18^{\circ} \mathrm{C}$ as well as when soil temperature dropped below $13^{\circ} \mathrm{C}$ at depths of both 2 and $4 \mathrm{~cm}$ positively correlated to both Rhizopus soft rot and bacterial root rot in North Carolina. A differential response was seen

Table 2. Correlations between bacterial root rot and Rhizopus soft rot susceptibility of sweetpotato (Beauregard) and soil texture, chemistry, and fertility measured at harvest in North Carolina and Louisiana, 2004 to $2006^{\mathrm{a}}$

\begin{tabular}{|c|c|c|c|c|c|c|c|c|c|c|}
\hline \multirow[b]{3}{*}{ Soil variable ${ }^{b}$} & \multicolumn{5}{|c|}{ North Carolina } & \multicolumn{5}{|c|}{ Louisiana } \\
\hline & \multirow[b]{2}{*}{ Mean (SD) } & \multicolumn{2}{|c|}{$\begin{array}{c}\text { Bacterial root } \\
\text { rot }\end{array}$} & \multicolumn{2}{|c|}{$\begin{array}{c}\text { Rhizopus soft } \\
\text { rot }\end{array}$} & \multirow[b]{2}{*}{ Mean (SD) } & \multicolumn{2}{|c|}{$\begin{array}{l}\text { Bacterial root } \\
\text { rot }\end{array}$} & \multicolumn{2}{|c|}{$\begin{array}{l}\text { Rhizopus soft } \\
\text { rot }\end{array}$} \\
\hline & & $\mathbf{C C}$ & $P$ value & $\mathrm{CC}$ & $P$ value & & $\mathrm{CC}$ & $P$ value & $\mathrm{CC}$ & $P$ value \\
\hline \multicolumn{11}{|l|}{ Texture } \\
\hline Sand (\%) & 78.3 (8.6) & 0.057 & 0.333 & -0.097 & 0.098 & $12.5(8.5)$ & 0.376 & 0.001 & -0.099 & 0.406 \\
\hline Silt (\%) & $7.0(3.5)$ & -0.021 & 0.719 & 0.046 & 0.434 & $71.0(9.0)$ & -0.442 & $<0.001$ & -0.028 & 0.814 \\
\hline Clay $(\%)$ & $14.7(6.4)$ & -0.068 & 0.246 & 0.105 & 0.072 & $16.6(4.9)$ & 0.153 & 0.196 & 0.222 & 0.059 \\
\hline \multicolumn{11}{|l|}{ Chemistry } \\
\hline Acidity $\left(\mathrm{meq} / 100 \mathrm{~cm}^{3}\right)$ & $1.10(0.44)$ & 0.245 & $<0.001$ & 0.218 & $<0.001$ & $1.18(0.36)$ & 0.078 & 0.513 & -0.012 & 0.917 \\
\hline Cation exchange capacity (meq/100 $\left.\mathrm{cm}^{3}\right)$ & $4.83(1.66)$ & 0.224 & $<0.001$ & 0.114 & 0.052 & $7.9(1.8)$ & -0.032 & 0.790 & -0.043 & 0.715 \\
\hline Humic matter $(\%)$ & $1.12(0.53)$ & -0.225 & $<0.001$ & -0.140 & 0.017 & $1.24(0.23)$ & -0.159 & 0.179 & 0.344 & 0.003 \\
\hline $\mathrm{pH}$ & $5.72(0.44)$ & -0.334 & $<0.001$ & -0.021 & 0.728 & $5.90(0.64)$ & -0.062 & 0.604 & 0.005 & 0.968 \\
\hline \multicolumn{11}{|l|}{ Fertility } \\
\hline $\mathrm{Ca}$ (index) & $37.8(8.9)$ & -0.099 & 0.091 & -0.096 & 0.101 & $50.6(8.4)$ & -0.177 & 0.133 & 0.135 & 0.254 \\
\hline $\mathrm{Cu}$ (index) & $84.8(64.0)$ & 0.253 & $<0.001$ & 0.140 & 0.0170 & $61.4(20.1)$ & -0.357 & 0.002 & -0.007 & 0.955 \\
\hline $\mathrm{K}$ (index) & $51.5(24.7)$ & 0.035 & 0.551 & -0.228 & $<0.001$ & $92.4(50.4)$ & 0.259 & 0.027 & -0.402 & $<0.001$ \\
\hline $\operatorname{Mg}(\%)$ & $10.4(3.9)$ & -0.061 & 0.301 & -0.104 & 0.078 & $12.6(4.1)$ & -0.044 & 0.714 & 0.010 & 0.936 \\
\hline Mn (index) & $64.6(39.0)$ & 0.066 & 0.265 & 0.275 & $<0.001$ & $1132(327)$ & -0.248 & 0.035 & -0.020 & 0.867 \\
\hline $\mathrm{P}$ (index) & $143.9(67.3)$ & 0.147 & 0.012 & 0.261 & $<0.001$ & $51.4(24.8)$ & 0.067 & 0.572 & -0.573 & $<0.001$ \\
\hline S (index) & $50.2(17.5)$ & 0.363 & $<0.001$ & -0.102 & 0.083 & $37.5(7.0)$ & 0.002 & 0.985 & 0.026 & 0.830 \\
\hline Zn (index) & $117.9(109.5)$ & 0.272 & $<0.001$ & 0.106 & 0.071 & $50.9(28.4)$ & -0.025 & 0.837 & 0.047 & 0.691 \\
\hline
\end{tabular}

a SD = standard deviation. Pearson's correlation coefficients (CC) were calculated for the pooled data set of 2004, 2005, and 2006 ( $n=75$ fields in North Carolina and 59 fields in Louisiana).

b Soil parameters are reported using the North Carolina Department of Agriculture Index (Hardy et al. 2008). 
to increased days in which soil temperatures exceeded $32^{\circ} \mathrm{C}$ at a depth of $2 \mathrm{~cm}$, with Rhizopus soft rot incidence showing a significant negative correlation at all time periods and bacterial root rot showing a significant positive correlation at all time periods, except the 7 days preharvest. At a depth of $4 \mathrm{~cm}$, there were no days which exceeded the high soil heat threshold in the 21 days preharvest. The time period of 28 days preharvest was not significantly correlated with Rhizopus soft rot. The correlation between days exceeding the high heat threshold over the entire growing season was significant, with a negative correlation to Rhizopus soft rot incidence and a highly significant positive correlation to bacterial root rot. In Louisiana, there were no correlations with low air temperatures or high soil temperatures but there was a weakly positive correlation between bacterial root rot and low soil temperature and a highly significant negative correlation between Rhizopus soft rot and low soil temperature index (Table 4).

Significant correlations were also seen in North Carolina but not in Louisiana to high and low soil moisture thresholds (Table 5), with Rhizopus soft rot incidence positively correlated to increased days experiencing high soil moisture at depths of 10,40 , or $100 \mathrm{~cm}$ at 21 and 28 days preharvest as well as the entire growing season. Bacterial root rot incidence was negatively correlated to high soil moisture at all depths in all time periods $(7,14,21$, and 28 days preharvest and entire growing season). Rhizopus soft rot incidence was correlated to increased number of days exceeding the low soil moisture threshold at all three depths, while bacterial root rot incidence was not correlated at any depth at any time period.

Stepwise regression followed by mixed-model analysis identified significant relationships between certain weather and soil parameters and Rhizopus soft rot and bacterial root rot incidence. In North Carolina, soil P, HM, air temperature, soil temperature at a depth of $2 \mathrm{~cm}$, and soil moisture differences between the 10- and 40-cm depths were all highly significant in explaining variation in Rhizopus soft rot incidence. Soil $\mathrm{pH}$, days exceeding the high soil temperature threshold for the last 14 days before harvest, and differences in soil moisture between the 40- and 100-cm soil depths for the last 14 to 21 days before harvest were all highly significant in explaining variation in bacterial root rot incidence. Because there were significant differences between the insecticide-treated and untreated strips in Louisiana, these were analyzed by stepwise regression separately. Variables related to low soil moisture were most influential in describing variation in Rhizopus soft rot incidence but air temperature, soil temperature, and humic acid were also significant (Table 6). For bacterial root rot in Louisiana, soil moisture variables were the most

Table 3. Correlations between bacterial root rot and Rhizopus soft rot susceptibility of sweetpotato (Beauregard) and mean air temperature, soil temperature, and soil moisture in Louisiana and North Carolina, 2004 to $2006^{\mathrm{a}}$

\begin{tabular}{|c|c|c|c|c|c|c|c|c|c|c|}
\hline \multirow[b]{3}{*}{ Weather days ${ }^{b}$} & \multicolumn{5}{|c|}{ North Carolina } & \multicolumn{5}{|c|}{ Louisiana } \\
\hline & \multirow[b]{2}{*}{ Mean (SD) } & \multicolumn{2}{|c|}{ Bacterial root rot } & \multicolumn{2}{|c|}{ Rhizopus soft rot } & \multirow[b]{2}{*}{ Mean (SD) } & \multicolumn{2}{|c|}{ Bacterial root rot } & \multicolumn{2}{|c|}{ Rhizopus soft rot } \\
\hline & & $\mathrm{CC}$ & $P$ value & $\mathrm{CC}$ & $P$ value & & $\mathrm{CC}$ & $P$ value & $\mathrm{CC}$ & $P$ value \\
\hline \multicolumn{11}{|l|}{$\mathrm{AT}\left({ }^{\circ} \mathrm{C}\right)$} \\
\hline 7 & $21.4(3.6)$ & -0.265 & $<0.0001$ & -0.210 & 0.0003 & $23.8(3.5)$ & -0.089 & 0.168 & 0.306 & $<0.0001$ \\
\hline 14 & $21.9(2.8)$ & -0.289 & $<0.0001$ & -0.207 & 0.0004 & $24.2(3.2)$ & -0.055 & 0.398 & 0.349 & $<0.0001$ \\
\hline 21 & $22.5(2.6)$ & -0.282 & $<0.0001$ & -0.213 & 0.0002 & $24.7(2.8)$ & -0.010 & 0.877 & 0.389 & $<0.0001$ \\
\hline 28 & $22.8(2.3)$ & -0.262 & $<0.0001$ & -0.221 & 0.0001 & $25.2(2.5)$ & 0.014 & 0.826 & 0.400 & $<0.0001$ \\
\hline Season & $25.1(0.8)$ & -0.120 & 0.0408 & -0.432 & $<0.0001$ & $26.4(0.9)$ & 0.260 & $<0.0001$ & 0.354 & $<0.0001$ \\
\hline \multicolumn{11}{|l|}{$\mathrm{ST}_{2}\left({ }^{\circ} \mathrm{C}\right)$} \\
\hline 7 & $22.2(3.8)$ & -0.282 & $<0.0001$ & -0.207 & 0.0004 & $24.6(3.7)$ & -0.089 & 0.168 & 0.314 & $<0.0001$ \\
\hline 14 & $22.7(2.9)$ & -0.301 & $<0.0001$ & -0.215 & 0.0002 & $25.1(3.4)$ & -0.056 & 0.383 & 0.356 & $<0.0001$ \\
\hline 21 & $23.0(2.7)$ & -0.290 & $<0.0001$ & -0.222 & 0.0001 & $25.6(2.9)$ & -0.013 & 0.837 & 0.394 & $<0.0001$ \\
\hline 28 & $23.5(2.4)$ & -0.271 & $<0.0001$ & -0.230 & $<0.0001$ & $26.1(2.6)$ & 0.005 & 0.935 & 0.406 & $<0.0001$ \\
\hline Season & $25.8(0.8)$ & -0.121 & 0.0403 & -0.431 & $<0.0001$ & $27.2(0.9)$ & 0.245 & 0.0001 & 0.361 & $<0.0001$ \\
\hline \multicolumn{11}{|l|}{$\mathrm{ST}_{4}\left({ }^{\circ} \mathrm{C}\right)$} \\
\hline 7 & $20.2(3.6)$ & -0.282 & $<0.0001$ & -0.208 & 0.0003 & $22.6(3.5)$ & -0.089 & 0.166 & 0.315 & $<0.0001$ \\
\hline 14 & $20.7(2.8)$ & -0.302 & $<0.0001$ & -0.218 & 0.0002 & $22.9(3.2)$ & -0.056 & 0.382 & 0.357 & $<0.0001$ \\
\hline 21 & $21.0(2.5)$ & -0.290 & $<0.0001$ & -0.224 & 0.0001 & $23.5(2.8)$ & -0.013 & 0.840 & 0.395 & $<0.0001$ \\
\hline 28 & $21.5(2.3)$ & -0.271 & $<0.0001$ & -0.231 & $<0.0001$ & $23.9(2.5)$ & 0.006 & 0.931 & 0.406 & $<0.0001$ \\
\hline Season & $23.7(0.8)$ & -0.121 & 0.0388 & -0.432 & $<0.0001$ & $25.0(0.9)$ & 0.244 & 0.0001 & 0.361 & $<0.0001$ \\
\hline \multicolumn{11}{|l|}{$\mathrm{SM}_{10}\left(\mathrm{~m}^{3} / \mathrm{m}^{3}\right)$} \\
\hline 7 & $0.29(0.04)$ & -0.401 & $<0.0001$ & 0.130 & 0.0262 & $0.22(0.06)$ & -0.028 & 0.663 & -0.220 & 0.0006 \\
\hline 14 & $0.28(0.05)$ & -0.312 & $<0.0001$ & 0.242 & $<0.0001$ & $0.22(0.05)$ & -0.062 & 0.334 & -0.077 & 0.235 \\
\hline 21 & $0.28(0.05)$ & -0.299 & $<0.0001$ & 0.344 & $<0.0001$ & $0.21(0.04)$ & -0.110 & 0.087 & 0.010 & 0.882 \\
\hline 28 & $0.28(0.05)$ & -0.362 & $<0.0001$ & 0.336 & $<0.0001$ & $0.21(0.03)$ & -0.198 & 0.002 & 0.038 & 0.555 \\
\hline Season & $0.28(0.03)$ & -0.325 & $<0.0001$ & 0.320 & $<0.0001$ & $0.24(0.05)$ & -0.404 & $<0.0001$ & 0.064 & 0.324 \\
\hline \multicolumn{11}{|l|}{$\mathrm{SM}_{40}\left(\mathrm{~m}^{3} / \mathrm{m}^{3}\right)$} \\
\hline 7 & $0.28(0.05)$ & -0.367 & $<0.0001$ & 0.230 & $<0.0001$ & $0.21(0.06)$ & -0.012 & 0.851 & -0.217 & 0.0007 \\
\hline 14 & $0.27(0.06)$ & -0.313 & $<0.0001$ & 0.296 & $<0.0001$ & $0.21(0.05)$ & -0.056 & 0.390 & -0.085 & 0.189 \\
\hline 21 & $0.27(0.06)$ & -0.316 & $<0.0001$ & 0.359 & $<0.0001$ & $0.20(0.04)$ & -0.111 & 0.085 & -0.003 & 0.985 \\
\hline 28 & $0.27(0.06)$ & -0.363 & $<0.0001$ & 0.349 & $<0.0001$ & $0.20(0.04)$ & -0.190 & 0.003 & 0.026 & 0.690 \\
\hline Season & $0.27(0.03)$ & -0.298 & $<0.0001$ & 0.322 & $<0.0001$ & $0.23(0.06)$ & -0.410 & $<0.0001$ & 0.060 & 0.350 \\
\hline \multicolumn{11}{|l|}{$\mathrm{SM}_{100}\left(\mathrm{~m}^{3} / \mathrm{m}^{3}\right)$} \\
\hline 7 & $0.24(0.07)$ & -0.340 & $<0.0001$ & 0.316 & $<0.0001$ & $0.18(0.05)$ & -0.139 & 0.030 & -0.108 & 0.092 \\
\hline 14 & $0.24(0.07)$ & -0.339 & $<0.0001$ & 0.311 & $<0.0001$ & $0.17(0.04)$ & -0.180 & 0.005 & -0.098 & 0.130 \\
\hline 21 & $0.24(0.07)$ & -0.368 & $<0.0001$ & 0.329 & $<0.0001$ & $0.17(0.04)$ & -0.216 & 0.0007 & -0.076 & 0.240 \\
\hline 28 & $0.24(0.07)$ & -0.401 & $<0.0001$ & 0.314 & $<0.0001$ & $0.17(0.04)$ & -0.237 & 0.0002 & -0.061 & 0.345 \\
\hline Season & $0.24(0.04)$ & -0.296 & $<0.0001$ & 0.287 & $<0.0001$ & $0.21(0.06)$ & -0.381 & $<0.0001$ & 0.007 & 0.919 \\
\hline
\end{tabular}

a SD = standard deviation. Pearson's correlation coefficients (CC) were calculated for the pooled dataset of 2004, 2005, and 2006 ( $n=75$ fields).

${ }^{b}$ Weather at days preharvest. Parameters were estimated using hourly site-specific weather data. AT = mean air temperature $\left({ }^{\circ} \mathrm{C}\right), \mathrm{ST}_{2}=$ mean soil temperature $\left({ }^{\circ} \mathrm{C}\right)$ at 2 -cm depth, $\mathrm{ST}_{4}=$ mean soil temperature $\left({ }^{\circ} \mathrm{C}\right)$ at 4-cm depth, $\mathrm{SM}_{10}=$ mean soil moisture $\left(\mathrm{m}^{3} / \mathrm{m}^{3}\right)$ at 10-cm depth, $\mathrm{SM}_{40}=$ mean soil moisture $\left(\mathrm{m}^{3} / \mathrm{m}^{3}\right)$ at 40-cm depth, and $\mathrm{SM}_{100}=$ mean soil moisture $\left(\mathrm{m}^{3} / \mathrm{m}^{3}\right)$ at $100-\mathrm{cm}$ depth. 
significant, but late-season air temperature and soil temperature as well as soil $\mathrm{S}$ were also significant.

\section{Discussion}

Beauregard, the sweetpotato cultivar used in this study, is considered moderately resistant to infection by $R$. stolonifer (Clark and Hoy 1994; Holmes and Stange 2002) and highly susceptible to root rot caused by $D$. dadantii (Clark et al. 1989). Our results, however, indicate that dramatic differences in postharvest disease susceptibility can occur in Beauregard sweetpotato from different harvests held under identical storage conditions. This occurred despite the absence, during the 3 years of this study, of extreme events such as flooding or early frost that are generally recognized to affect postharvest disease susceptibility (Ahn et al. 1980; Clark et al. 2013; Kushman and Deonier 1958; Kushman et al. 1954; Ton and Hernandez 1978). A wide range of incidence of both bacterial root rot and Rhizopus soft rot developed when sweetpotato roots from different fields in a single growing season or from different growing seasons were inoculated following storage under uniform conditions. Although, over the 3 -year study, there was a weak positive correlation in North Carolina and a weak negative correlation in Louisiana between incidence of Rhizopus soft rot and bacterial root rot, the relationships varied from year to year. The correlation in Louisiana was positive in 2004 and negative in 2006. It appears that these two diseases may respond similarly to some preharvest variables but differently to other variables. It is clear that environment has a large influence on susceptibility of Beauregard but research is needed to determine whether other genotypes respond similarly or if this is an indication of a broader genotype by environment interaction.

Although the ranges of disease incidence were very similar between Louisiana and North Carolina, correlations between disease incidence and soil, weather, and cultural variables differed greatly between the two states. Sweetpotato crops are grown in North Carolina in sandy coastal plain soils whereas, in Louisiana, they are grown in wind-deposited silt loam ridges. Not only do the soils have different physical and chemical properties but also the climates are quite different between the two states. Thus, although the study identified preharvest soil and weather factors which were related to sweetpotato susceptibility to postharvest Rhizopus soft rot and bacterial root rot in each state, it appears that any effort to develop predictive models for these diseases will have to be calibrated to local conditions.

Although many preharvest variables were significantly correlated to variations in Rhizopus soft rot or bacterial root rot when analyzed individually, many of these variables are correlated to each other, requiring approaches that adjust for multicollinear variables to understand the variables that truly have the greatest influence on disease incidence. When data sets for Louisiana and North Carolina were combined and analyzed by ridge regression with stepwise selection and partial least squares regression, several soil factors were indicated to have an influence on Rhizopus soft rot incidence: soil $\mathrm{S}$, CEC, K, magnesium, and Zn. However, when multiple regression with stepwise selection followed by a reduced mixed-model analysis was performed on the data for each state separately, a somewhat different group of variables was identified as having the greatest

Table 4. Correlations between bacterial root rot and Rhizopus soft rot susceptibility of sweetpotato (Beauregard) and soil and air temperatures above and below defined thresholds in Louisiana and North Carolina, 2004 to $2006^{\mathrm{a}}$

\begin{tabular}{|c|c|c|c|c|c|c|c|c|c|c|}
\hline \multirow[b]{3}{*}{ Stress (days) ${ }^{\mathbf{b}}$} & \multicolumn{5}{|c|}{ North Carolina } & \multicolumn{5}{|c|}{ Louisiana } \\
\hline & \multirow[b]{2}{*}{ Mean (SD) } & \multicolumn{2}{|c|}{ Bacterial root rot } & \multicolumn{2}{|c|}{ Rhizopus soft rot } & \multirow[b]{2}{*}{ Mean (SD) } & \multicolumn{2}{|c|}{ Bacterial root rot } & \multicolumn{2}{|c|}{ Rhizopus soft rot } \\
\hline & & $\mathrm{CC}$ & $P$ value & $\mathrm{CC}$ & $P$ value & & $\mathrm{CC}$ & $P$ value & $\mathrm{CC}$ & $P$ value \\
\hline \multicolumn{11}{|l|}{ AT-L } \\
\hline 7 & $0.22(0.67)$ & 0.183 & 0.0017 & 0.291 & $<0.0001$ & $2.69(2.41)$ & 0.066 & 0.3097 & -0.204 & 0.0014 \\
\hline 14 & $0.37(0.99)$ & 0.239 & $<0.0001$ & 0.242 & $<0.0001$ & $4.73(4.28)$ & 0.069 & 0.2866 & -0.230 & $<0.0001$ \\
\hline 21 & $0.37(0.99)$ & 0.239 & $<0.0001$ & 0.242 & $<0.0001$ & $6.29(5.98)$ & 0.273 & 0.6723 & -0.352 & $<0.0001$ \\
\hline 28 & $0.37(0.99)$ & 0.239 & $<0.0001$ & 0.242 & $<0.0001$ & $7.08(7.14)$ & 0.023 & 0.7234 & -0.384 & $<0.0001$ \\
\hline Season & $0.39(0.99)$ & 0.323 & $<0.0001$ & 0.242 & $<0.0001$ & $13.55(11.88)$ & -0.029 & 0.6527 & -0.388 & $<0.0001$ \\
\hline \multicolumn{11}{|l|}{ ST- $\mathrm{H}_{2}$} \\
\hline 7 & $0.52(1.04)$ & 0.036 & 0.5416 & -0.263 & $<0.0001$ & $1.83(2.31)$ & -0.088 & 0.1714 & 0.291 & $<0.0001$ \\
\hline 14 & $0.78(1.33)$ & 0.179 & 0.0023 & -0.142 & 0.0151 & $4.38(4.57)$ & -0.082 & 0.2062 & 0.345 & $<0.0001$ \\
\hline 21 & $1.37(2.13)$ & 0.128 & 0.0288 & -0.162 & 0.0055 & $7.70(6.69)$ & 0.016 & 0.8030 & 0.352 & $<0.0001$ \\
\hline 28 & $2.56(3.13)$ & 0.128 & 0.0289 & -0.151 & 0.0100 & $11.69(8.56)$ & 0.074 & 0.2508 & 0.345 & $<0.0001$ \\
\hline Season & $29.56(12.52)$ & 0.349 & $<0.0001$ & -0.358 & $<0.0001$ & $56.39(14.93)$ & 0.448 & $<0.0001$ & 0.213 & 0.0008 \\
\hline \multicolumn{11}{|l|}{ ST- $\mathrm{H}_{4}$} \\
\hline 7 & 0 & NA & NA & NA & NA & $0.05(0.28)$ & -0.042 & 0.5139 & 0.120 & 0.0617 \\
\hline 14 & 0 & NA & NA & NA & NA & $0.08(0.33)$ & -0.013 & 0.8367 & 0.016 & 0.8006 \\
\hline 21 & 0 & NA & NA & NA & NA & $0.20(0.60)$ & 0.083 & 0.1960 & 0.157 & 0.0142 \\
\hline 28 & $0.01(0.12)$ & -0.030 & 0.6069 & -0.069 & 0.2429 & $0.38(0.80)$ & 0.096 & 0.1347 & 0.142 & 0.0270 \\
\hline Season & $1.19(1.13)$ & 0.449 & $<0.0001$ & -0.204 & 0.0005 & $01.67(2.62)$ & 0.274 & $<0.0001$ & -0.222 & 0.0005 \\
\hline \multicolumn{11}{|l|}{$\mathrm{ST}-\mathrm{L}_{2}$} \\
\hline 7 & $1.06(1.52)$ & 0.323 & $<0.0001$ & 0.210 & 0.0003 & $0.89(1.48)$ & 0.113 & 0.0790 & -0.277 & $<0.0001$ \\
\hline 14 & $1.27(2.05)$ & 0.302 & $<0.0001$ & 0.219 & 0.0002 & $1.36(2.39)$ & 0.161 & 0.0124 & -0.294 & $<0.0001$ \\
\hline 21 & $1.67(2.86)$ & 0.308 & $<0.0001$ & 0.223 & 0.0001 & $1.52(2.82)$ & 0.169 & 0.0086 & -0.314 & $<0.0001$ \\
\hline 28 & $1.92(3.47)$ & 0.312 & $<0.0001$ & 0.233 & $<0.0001$ & $1.62(3.16)$ & 0.175 & 0.0064 & -0.337 & $<0.0001$ \\
\hline Season & $2.21(3.75)$ & 0.334 & $<0.0001$ & 0.218 & 0.0002 & $1.74(3.38)$ & 0.165 & 0.0103 & -0.336 & $<0.0001$ \\
\hline \multicolumn{11}{|l|}{ ST-L 4} \\
\hline 7 & $1.03(1.47)$ & 0.270 & $<0.0001$ & 0.222 & 0.0001 & $0.83(1.33)$ & 0.135 & 0.0362 & -0.0242 & 0.0001 \\
\hline 14 & $1.26(2.04)$ & 0.268 & $<0.0001$ & 0.236 & $<0.0001$ & $1.24(2.12)$ & 0.167 & 0.0093 & -0.252 & $<0.0001$ \\
\hline 21 & $1.62(2.76)$ & 0.275 & $<0.0001$ & 0.242 & $<0.0001$ & $1.40(2.53)$ & 0.176 & 0.0061 & -0.282 & $<0.0001$ \\
\hline 28 & $1.84(3.31)$ & 0.280 & $<0.0001$ & 0.247 & $<0.0001$ & $1.50(2.85)$ & 0.183 & 0.0042 & -0.314 & $<0.0001$ \\
\hline Season & $2.06(3.60)$ & 0.307 & $<0.0001$ & 0.241 & $<0.0001$ & $1.55(2.95)$ & 0.181 & 0.0047 & -0.319 & $<0.0001$ \\
\hline
\end{tabular}

${ }^{a} \mathrm{SD}=$ standard deviation. Pearson's correlation coefficients (CC) were calculated for the pooled dataset of 2004, 2005, and $2006(n=75$ fields). NA = not applicable because no stress days were recorded.

${ }^{b}$ Stress parameters were estimated using site-specific weather data and calculated as the number of days when the defined threshold was exceeded for any hour of the day. AT- $\mathrm{L}=$ air temperature $<18^{\circ} \mathrm{C}, \mathrm{ST}-\mathrm{H}_{2}=$ soil temperature $>32^{\circ} \mathrm{C}$ at $2 \mathrm{~cm}$, ST $-\mathrm{H}_{4}=$ soil temperature $>32^{\circ} \mathrm{C}$ at $4 \mathrm{~cm}, \mathrm{ST}-\mathrm{L}_{2}=$ soil temperature $<13^{\circ} \mathrm{C}$ at $2 \mathrm{~cm}$, and $\mathrm{ST}-\mathrm{L}_{4}=$ soil temperature $<13^{\circ} \mathrm{C}$ at $4 \mathrm{~cm}$. 
influence. Predictive models composed of different variables were significant for each disease. For Rhizopus soft rot, percent soil HM at harvest had a greater effect on Rhizopus soft rot incidence than changing levels of the soil $\mathrm{P}$ index or percent calcium (Ca), although all are significant in the model.

In this study, the soil samples were taken at harvest to mimic a normal fall sampling time used to predict soil fertility needs for the next season. Therefore, the results of certain nutrients such as soil $\mathrm{P}$ are presented as an index by the soil testing agency. The index serves as a guide for the next season's application needs but not as a measure of the absolute value. The rationale for using a fall soil test, instead of a spring preplant soil test, was to develop a predictive model for disease susceptibility that can be used by sweetpotato growers incorporating already utilized techniques. Research is needed to determine the effect of specific amendments with nutrients such as $\mathrm{K}, \mathrm{P}$, or $\mathrm{Ca}$ on the susceptibility of sweetpotato to Rhizopus soft rot.

In North Carolina, soil $\mathrm{pH}$ levels at harvest, which ranged from 4.6 to 6.5 (average $=5.7$ ) in the fields used in this study, were identified by the mixed-model analysis as a significant variable of bacterial root rot. Acidic soil pH is known to reduce the occurrence of another bacterial disease of sweetpotato, soil rot or pox caused by Streptomyces ipomoeae (Clark et al. 2013). However, unlike bacterial root rot, soil rot infection occurs in the field, with the soil $\mathrm{pH}$ levels directly affecting the pathogen's ability to induce disease. Low soil $\mathrm{pH}$ treatments also affect sweetpotato growth by reducing the marketable yield of 'Jewel' sweetpotato (Ristaino and Averre 1992). We found that higher soil $\mathrm{pH}$ levels were correlated with reduced susceptibility to bacterial root rot. Further study is needed to determine the effect of soil $\mathrm{pH}$ during the growing season on Beauregard sweetpotato storage root physiology to determine how soil $\mathrm{pH}$ is affecting nutrient levels or other storage root tissue factors which, in turn, affect postharvest bacterial root rot susceptibility.

Several weather variables were identified as significant in the models, with soil moisture, soil temperature, and air temperature having the greatest overall effect on Rhizopus soft rot incidence. For all three weather variables, there does not appear to be a specific preharvest time period that is more important to explaining Rhizopus soft rot susceptibility. For the bacterial root rot model, low soil moisture and high soil temperature stress were significant variables in both states.

In general, there are limited research data to explain the correlations between environmental conditions during the growing season and postharvest decay susceptibility of sweetpotato roots. A main limiting factor of the published research on this topic is that the specific pathogen was not identified but only referred to in general terms such as "decay" or "rot". Another complication is that Beauregard is

Table 5. Correlations between bacterial root rot and Rhizopus soft rot susceptibility of sweetpotato (Beauregard) and high and low soil moisture above and below defined thresholds in Louisiana and North Carolina, 2004 to $2006^{\mathrm{a}}$

\begin{tabular}{|c|c|c|c|c|c|c|c|c|c|c|}
\hline \multirow[b]{3}{*}{ Soil (days) ${ }^{b}$} & \multicolumn{5}{|c|}{ North Carolina } & \multicolumn{5}{|c|}{ Louisiana } \\
\hline & \multirow[b]{2}{*}{ Mean (SD) } & \multicolumn{2}{|c|}{ Bacterial root rot } & \multicolumn{2}{|c|}{ Rhizopus soft rot } & \multirow[b]{2}{*}{ Mean (SD) } & \multicolumn{2}{|c|}{ Bacterial root rot } & \multicolumn{2}{|c|}{ Rhizopus soft rot } \\
\hline & & $\mathrm{CC}$ & $P$ value & $\mathrm{CC}$ & $P$ value & & $\mathrm{CC}$ & $P$ value & $\mathrm{CC}$ & $P$ value \\
\hline \multicolumn{11}{|l|}{$\mathrm{SM}-\mathrm{H}_{10}$} \\
\hline 7 & $3.29(2.52)$ & -0.358 & $<0.0001$ & 0.093 & 0.1142 & $1.09(1.98)$ & 0.016 & 0.7974 & -0.395 & $<0.0001$ \\
\hline 14 & $6.30(4.70)$ & -0.414 & $<0.0001$ & 0.064 & 0.2764 & $2.20(3.42)$ & -0.056 & 0.3876 & -0.284 & $<0.0001$ \\
\hline 21 & $9.23(6.78)$ & -0.409 & $<0.0001$ & 0.205 & 0.0004 & $2.53(3.58)$ & -0.006 & 0.9223 & -0.262 & $<0.0001$ \\
\hline 28 & 11.97 (9.17) & -0.467 & $<0.0001$ & 0.221 & 0.0001 & $3.19(3.81)$ & -0.040 & 0.5332 & -0.259 & $<0.0001$ \\
\hline Season & $46.84(23.90)$ & -0.395 & $<0.0001$ & 0.254 & $<0.0001$ & $28.54(30.40)$ & -0.347 & $<0.0001$ & -0.048 & 0.4607 \\
\hline \multicolumn{11}{|l|}{$\mathrm{SM}-\mathrm{H}_{40}$} \\
\hline 7 & $2.53(3.03)$ & -0.351 & $<0.0001$ & 0.131 & 0.0254 & $0.81(1.82)$ & 0.024 & 0.7129 & -0.363 & $<0.0001$ \\
\hline 14 & $4.99(5.50)$ & -0.385 & $<0.0001$ & 0.094 & 0.1146 & $1.60(3.25)$ & -0.044 & 0.4960 & -0.293 & $<0.0001$ \\
\hline 21 & $7.32(7.56)$ & -0.424 & $<0.0001$ & 0.182 & 0.0019 & $1.67(3.31)$ & -0.047 & 0.4657 & -0.308 & $<0.0001$ \\
\hline 28 & $9.26(9.90)$ & -0.492 & $<0.0001$ & 0.190 & 0.0011 & $1.79(3.47)$ & -0.054 & 0.3988 & -0.315 & $<0.0001$ \\
\hline Season & $26.60(21.33)$ & -0.361 & $<0.0001$ & 0.228 & $<0.0001$ & $19.40(28.40)$ & -0.286 & $<0.0001$ & -0.076 & 0.2368 \\
\hline \multicolumn{11}{|l|}{ SM-H ${ }_{100}$} \\
\hline 7 & $1.62(2.75)$ & -0.311 & $<0.0001$ & 0.108 & 0.0637 & $0.18(1.02)$ & -0.030 & 0.6396 & 0.017 & 0.7980 \\
\hline 14 & $3.27(5.16)$ & -0.314 & $<0.0001$ & 0.103 & 0.0792 & $0.21(1.25)$ & -0.032 & 0.6184 & 0.022 & 0.7388 \\
\hline 21 & $4.73(7.22)$ & -0.386 & $<0.0001$ & 0.141 & 0.0158 & $0.26(1.30)$ & -0.042 & 0.5162 & 0.004 & 0.9450 \\
\hline 28 & $5.96(9.08)$ & -0.439 & $<0.0001$ & 0.178 & 0.0022 & $0.38(1.77)$ & -0.050 & 0.4419 & -0.046 & 0.4717 \\
\hline Season & $11.23(14.67)$ & -0.417 & $<0.0001$ & 0.198 & 0.0007 & $17.95(29.14)$ & -0.290 & $<0.0001$ & -0.053 & 0.4147 \\
\hline \multicolumn{11}{|l|}{ SM-L $\mathrm{L}_{10}$} \\
\hline 7 & $0.06(0.47)$ & 0.081 & 0.1712 & 0.034 & 0.5602 & $1.52(2.46)$ & -0.008 & 0.9013 & -0.073 & 0.2604 \\
\hline 14 & $0.41(1.23)$ & 0.006 & 0.9201 & -0.261 & $<0.0001$ & $2.61(3.88)$ & 0.068 & 0.2928 & -0.251 & $<0.0001$ \\
\hline 21 & $0.74(2.12)$ & 0.054 & 0.3598 & -0.308 & $<0.0001$ & $4.35(5.35)$ & 0.157 & 0.0147 & -0.324 & $<0.0001$ \\
\hline 28 & $0.79(2.28)$ & 0.055 & 0.3516 & -0.307 & $<0.0001$ & $5.79(6.35)$ & 0.174 & 0.0068 & -0.239 & 0.0002 \\
\hline Season & $1.70(4.98)$ & -0.002 & 0.9675 & -0.326 & $<0.0001$ & $13.01(16.56)$ & 0.282 & $<0.0001$ & -0.314 & $<0.0001$ \\
\hline \multicolumn{11}{|l|}{ SM-L 40} \\
\hline 7 & $0.07(0.38)$ & 0.017 & 0.7733 & -0.028 & 0.6394 & $1.88(2.87)$ & 0.077 & 0.2307 & -0.068 & 0.2899 \\
\hline 14 & $0.64(1.92)$ & -0.026 & 0.6639 & -0.295 & $<0.0001$ & $3.90(5.29)$ & 0.173 & 0.0069 & -0.249 & $<0.0001$ \\
\hline 21 & $1.12(3.18)$ & 0.008 & 0.8916 & -0.329 & $<0.0001$ & $6.60(8.01)$ & 0.212 & 0.0009 & -0.299 & $<0.0001$ \\
\hline 28 & $1.67(4.75)$ & 0.004 & 0.9522 & -0.309 & $<0.0001$ & $8.99(10.44)$ & 0.245 & 0.0001 & -0.266 & $<0.0001$ \\
\hline Season & $3.12(9.37)$ & -0.001 & 0.9811 & -0.303 & $<0.0001$ & $22.84(28.94)$ & 0.331 & $<0.0001$ & -0.278 & $<0.0001$ \\
\hline \multicolumn{11}{|l|}{ SM-L $L_{100}$} \\
\hline 7 & $1.01(2.37)$ & 0.055 & 0.3511 & -0.348 & $<0.0001$ & $3.65(3.38)$ & 0.296 & $<0.0001$ & 0.106 & 0.0989 \\
\hline 14 & $1.82(4.43)$ & 0.026 & 0.6586 & -0.351 & $<0.0001$ & $7.64(6.33)$ & 0.377 & $<0.0001$ & 0.030 & 0.6375 \\
\hline 21 & $2.69(6.55)$ & 0.018 & 0.7627 & -0.335 & $<0.0001$ & $11.40(9.13)$ & 0.397 & $<0.0001$ & -0.052 & 0.4199 \\
\hline 28 & $3.49(8.38)$ & 0.019 & 0.7443 & -0.313 & $<0.0001$ & $14.88(12.23)$ & 0.391 & $<0.0001$ & -0.096 & 0.1377 \\
\hline Season & $6.36(16.37)$ & 0.034 & 0.5617 & -0.316 & $<0.0001$ & $36.18(37.34)$ & 0.408 & $<0.0001$ & -0.214 & 0.0008 \\
\hline
\end{tabular}

a SD = standard deviation. Pearson's correlation coefficients $(C C)$ were calculated for the pooled data set of 2004,2005 , and $2006(n=75$ fields).

b Soil parameters were estimated using site-specific weather data and calculated as the number of days when the defined threshold was exceeded for any hour of the day. SM-H $\mathrm{H}_{10}=$ soil moisture $>0.31\left(\mathrm{~m}^{3} / \mathrm{m}^{3}\right)$ at depth of $10 \mathrm{~cm}, \mathrm{SM}-\mathrm{H}_{40}=$ soil moisture $>0.31\left(\mathrm{~m}^{3} / \mathrm{m}^{3}\right)$ at $40 \mathrm{~cm}, \mathrm{SM}-\mathrm{H}_{100}=\mathrm{soil} \mathrm{moisture}>0.31\left(\mathrm{~m}^{3} / \mathrm{m}^{3}\right)$ at $100 \mathrm{~cm}, \mathrm{SM}-\mathrm{L}_{10}=$ soil moisture $<0.15\left(\mathrm{~m}^{3} / \mathrm{m}^{3}\right)$ at $10 \mathrm{~cm}, \mathrm{SM}-\mathrm{L}_{40}=$ soil moisture $<0.15\left(\mathrm{~m}^{3} / \mathrm{m}^{3}\right)$ at $40 \mathrm{~cm}$, and SM-L $100=\mathrm{soil} \mathrm{moisture}<0.15\left(\mathrm{~m}^{3} / \mathrm{m}^{3}\right)$ at $100 \mathrm{~cm}$ 
a relatively new cultivar (Rolston et al. 1987) with different disease susceptibilities than older cultivars used in earlier studies. Furthermore, previous studies focused on extreme values of a limited number of variables (e.g., flooding) while the present study indicates that a complex interaction of numerous variables within a "normal range" of variation can have profound effects on disease susceptibility. In earlier studies, 'Porto Rico' grown in Louisiana was more susceptible to postharvest decay (noninoculated) when harvested from a field that experienced a cold, wet period prior to harvest (Kushman et al. 1954). Extending the harvest season into December confirmed that cold, wet soils decrease sweetpotato quality by increasing internal breakdown (Kushman and Deonier 1958). Likewise, flooding increased decay at harvest (Ton and Hernandez 1978) (averaged over 17 to 28 sweetpotato cultivars) and in Jewel storage roots during curing and storage (Thompson et al. 1992). Thompson et al. (1992) also found a slight increase in decay in Jewel storage roots receiving the least irrigation water. A field study using Jewel and 'Centennial' sweetpotato found that greater losses were experienced with a 3-day flooding period than with a 1- or 2-day flooding period (Corey et al. 1982). A growth chamber study (Ahn et al. 1980) further indicated that storage roots grown in warm $\left(24\right.$ to $\left.34^{\circ} \mathrm{C}\right)$, water-saturated soils for 1 week prior to harvest resulted in greater root decay and quality reductions than storage roots grown in cold $\left(4^{\circ} \mathrm{C}\right)$, water-saturated soils or nonsaturated soils at either temperature. Though the specific pathogens causing decay were not recorded in any of these studies, the results suggest that soil moisture levels, soil temperature, and flood stress during the growing season are related to postharvest disease susceptibility.

In most studies of extreme stress conditions such as flooding, infection is initiated in the field and continues in storage and it is expected that preharvest conditions will have a profound effect on the infection process as well as sweetpotato susceptibility. In this study, however, uniform inoculations were performed on apparently healthy storage roots that had been in uniform storage conditions for 100 to 120 days and the effect of preharvest conditions is presumed to be solely on sweetpotato susceptibility rather than the infection process. Soil moisture and temperature also affect storage root morphology and physiology which, in turn, could affect disease susceptibility. Sweetpotato plants grown under drought stress conditions in a greenhouse produced significantly thicker periderm tissue than those grown in a nondrought-stressed environment (Harrison et al. 2006). Villavicencio et al. (2007) studied the effect of three growing temperature regimes on storage root characteristics and found a positive correlation between pectinase activity and growth temperature, indicating that temperature has an effect on strength of cell wall bonds, which could influence susceptibility to soft rot pathogens. They also found a positive correlation between periderm lignification and growth temperature, indicating that storage roots grown at higher temperatures are likely to be more resistant to compression type injuries, which are known to favor Rhizopus infection (Holmes and Stange 2002). Although not measured in this study, resistance to mechanical injury could play a role in disease susceptibility and requires further study.

The use of environmental stress thresholds (e.g., exceeding a threshold set for high soil temperature or low soil moisture) to estimate the postharvest response of sweetpotato (e.g., effect on storability or disease susceptibility) has not been previously reported. The predictive models developed for Rhizopus soft rot and bacterial root rot were highly significant using the thresholds as defined in this study. The thresholds for temperature and soil moisture used in this analysis were chosen using preliminary field research results to describe physiological responses of sweetpotato to environmental stress (Villordon et al. 2009). Other values to describe the thresholds (e.g., using a threshold

Table 6. Final reduced models selected by stepwise regression followed by mixed-model analysis to explain the postharvest susceptibility of sweetpotato (Beauregard) to bacterial root rot and Rhizopus soft rot using weather and soil parameters ${ }^{\mathrm{a}}$

\begin{tabular}{|c|c|c|c|c|c|c|c|c|c|c|c|}
\hline \multicolumn{6}{|c|}{ North Carolina } & \multicolumn{6}{|c|}{ Louisiana } \\
\hline Parameter & $\begin{array}{l}\text { Parameter } \\
\text { estimate }\end{array}$ & Error & df & t Value & $P$ value & Parameter & $\begin{array}{l}\text { Parameter } \\
\text { estimate }\end{array}$ & Error & df & t Value & $P$ value \\
\hline Rhizopus soft rot & & & & & & Untreated strips & & & & & \\
\hline Intercept & 96.31 & 99.00 & 2 & 0.97 & 0.433 & Intercept & -138.83 & 58.73 & 2 & -2.36 & 0.142 \\
\hline $\mathrm{P}$ & 0.15 & 0.03 & 113 & 4.67 & $<0.001$ & Canner yield & 2.11 & 0.57 & 59 & 3.67 & 0.0005 \\
\hline $\mathrm{Ca}$ & -0.60 & 0.25 & 113 & -2.39 & 0.019 & $\mathrm{HM}$ & 42.10 & 12.53 & 59 & 3.36 & 0.0014 \\
\hline $\mathrm{HM}$ & -26.78 & 4.87 & 113 & -5.50 & $<0.001$ & AT 28 days & 107.73 & 33.02 & 59 & 3.26 & 0.0018 \\
\hline AT season & -154.11 & 40.66 & 113 & -3.79 & $<0.001$ & $\mathrm{ST}_{4} 28$ days & -107.67 & 33.07 & 59 & -3.26 & 0.0019 \\
\hline $\mathrm{SM}_{10}-\mathrm{SM}_{40} 14$ days & -750.42 & 149.57 & 113 & -5.02 & $<0.001$ & ST- $\mathrm{H}_{2} 21$ days & 1.37 & 0.59 & 59 & 2.31 & 0.0245 \\
\hline $\mathrm{ST}_{2}$ season & 148.90 & 39.99 & 113 & 3.72 & $<0.001$ & SM-L $L_{10} 21$ days & -7.60 & 1.16 & 59 & -6.55 & $<0.0001$ \\
\hline SM-L ${ }_{10}-\mathrm{SM}-\mathrm{L}_{40}$ season & 8.52 & 2.38 & 113 & 3.59 & $<0.001$ & SM- $\mathrm{L}_{10} 28$ days & 10.88 & 1.47 & 59 & 7.42 & $<0.0001$ \\
\hline SM-L ${ }_{10}-\mathrm{SM}-\mathrm{L}_{40} 28$ days & -11.05 & 3.69 & 113 & -2.99 & 0.003 & SM- $\mathrm{H}_{10} 28$ days & -4.16 & 0.79 & 59 & -5.27 & $<0.0001$ \\
\hline$\cdots$ & $\ldots$ & $\cdots$ & $\ldots$ & $\ldots$ & $\ldots$ & $\begin{array}{l}\text { SM- } \mathrm{L}_{40} 21 \text { days } \\
\text { Treated strips }\end{array}$ & -5.06 & 1.02 & 59 & -4.98 & $<0.0001$ \\
\hline$\ldots$ & $\ldots$ & $\ldots$ & $\ldots$ & $\ldots$ & $\ldots$ & Intercept & 46.29 & 5.67 & 2 & 8.17 & 0.0147 \\
\hline$\ldots$ & $\ldots$ & $\ldots$ & $\ldots$ & $\ldots$ & $\ldots$ & ST- $\mathrm{H}_{2} 21$ days & 1.48 & 0.53 & 60 & 2.81 & 0.0067 \\
\hline Bacterial root rot & & & & & & Untreated strips & & & & & \\
\hline Intercept & 115.4 & 27.52 & 2 & 4.18 & 0.053 & Intercept & 38.43 & 6.04 & 2 & 6.36 & 0.0239 \\
\hline $\mathrm{pH}$ & -15.06 & 3.91 & 115 & -3.85 & $<0.001$ & SM-L 100 season & 0.24 & 0.09 & 61 & 2.71 & 0.0087 \\
\hline ST- $\mathrm{H}_{2} 14$ days & 5.06 & 1.39 & 115 & 3.64 & $<0.001$ & Treated strips & & & & & \\
\hline SM-L $\mathrm{L}_{10}-\mathrm{SM}-\mathrm{L}_{100} 21$ days & 3.99 & 1.80 & 115 & 2.21 & 0.029 & Intercept & 196.34 & 28.51 & 2 & 6.89 & 0.0204 \\
\hline SM-H 4014 days & 1.46 & 0.50 & 115 & 2.92 & 0.004 & \% US\#1 & 0.33 & 0.10 & 59 & 3.30 & 0.0016 \\
\hline $\mathrm{SM}_{40}-\mathrm{SM}_{100} 14$ days & -793.97 & 255.19 & 115 & -3.11 & 0.002 & S & 0.82 & 0.31 & 59 & 2.67 & 0.0099 \\
\hline $\mathrm{SM}_{10}-\mathrm{SM}_{100} 21$ days & 1051.31 & 226.82 & 115 & 4.63 & $<0.001$ & $\mathrm{SM}_{40}$ season & -986.55 & 122.11 & 59 & -8.08 & $<0.0001$ \\
\hline$\ldots$ & $\ldots$ & $\ldots$ & $\ldots$ & $\ldots$ & $\ldots$ & $\mathrm{SM}_{100} 21$ days & 241.10 & 98.31 & 59 & 2.45 & 0.0172 \\
\hline$\ldots$ & $\ldots$ & $\ldots$ & $\ldots$ & $\ldots$ & $\ldots$ & AT-L 21 days & -1.47 & 0.44 & 59 & -3.31 & 0.0016 \\
\hline$\ldots$ & $\ldots$ & $\ldots$ & $\ldots$ & $\ldots$ & $\ldots$ & ST- $\mathrm{H}_{2} 7$ days & -2.48 & 1.08 & 59 & -2.29 & 0.0257 \\
\hline$\ldots$ & $\ldots$ & $\ldots$ & $\ldots$ & $\ldots$ & $\ldots$ & SM-L 1028 days & -1.72 & 0.47 & 59 & -3.64 & 0.0006 \\
\hline$\ldots$ & $\ldots$ & $\ldots$ & $\ldots$ & $\ldots$ & $\ldots$ & SM-H 40 season & 0.89 & 0.23 & 59 & 3.89 & 0.0003 \\
\hline
\end{tabular}


of $<12^{\circ} \mathrm{C}$ for low air temperature as opposed to $<13^{\circ} \mathrm{C}$ ) were examined in preliminary analyses (data not shown), and the threshold values used in the final analysis were selected because they best described this dataset. Future research will likely refine threshold values for environmental stress as affecting sweetpotato physiology and potentially further improve their value in predictive models.

Knowledge of how preharvest environmental variables affect postharvest disease incidence might be used to develop location-specific predictive models to use in decision support systems. A packer might use a decision support system to decide whether fungicide application is needed when packing sweetpotato from a particular field or harvest date. Alternatively, a grower might use a decision support system to adjust cultural practices such as fertilization, irrigation, or others to favor development of a more resistant crop. This study produced a detailed dataset which will be of use for validating disease prediction models using results from future studies. This work represents a first step to developing a weather-based decision-making system for predicting postharvest disease susceptibility of sweetpotato based on preharvest conditions.

To develop a practical, reliable decision support system will require extensive future research to corroborate the influence of individual variables in controlled experiments, to understand how the variables interact with each other, and to determine the geographical range for which the given model is applicable (i.e., agroclimatic region of country, state, or more localized). This is a daunting challenge given the large number of diverse variables that have been implicated in this study. An approach that might be pursued as an alternative or in parallel to modeling studies would be to investigate the possibility that the influential variables induce common responses in sweetpotato, such as a stress response, that might be used as an indicator of resistance or susceptibility. Preliminary studies have found some correlations with periderm color and phenolic contents (C. A. Clark, B. A. Edmunds, and G. J. Holmes, unpublished) but other possibilities include components such as resin glycosides or sugars (Harrison et al. 2001, 2008; Muhanna and Rees 2004). Regardless of which course proves most fruitful, the great range of variation in postharvest disease susceptibility documented in this study provides an opportunity for exploitation to reduce reliance on prophylactic use of fungicides and improve sweetpotato storage and marketing.

\section{Acknowledgments}

This research was supported by the United States Department of Agriculture CSREES Risk Avoidance and Mitigation Program (project number NC09197). We thank C. Arrellano, Y. Ge, B. Marx, and M. Zhang for statistical analysis support; and M. Adams, E. Gray, and M. Hoy for technical assistance. Approved for publication by the Director of the Louisiana Agricultural Experiment Station as manuscript number 2014-240-18914.

\section{Literature Cited}

Ahn, J. K., Collins, W. W., and Pharr, D. M. 1980. Influence of preharvest temperature and flooding on sweet potato roots in storage. HortScience 15:261-263.

Clark, C. A., Ferrin, D. M., Smith, T. P., and Holmes, G. J., eds. 2013. Compendium of Sweetpotato Diseases, Pests, and Disorders, 2nd ed. The American Phytopathological Society, St. Paul, MN.

Clark, C. A., and Hoy, M. W. 1994. Identification of resistance in sweetpotato to Rhizopus soft rot using two inoculation methods. Plant Dis. 78:1078-1082.

Clark, C. A., Wilder-Ayers, J. A., and Duarte, V. 1989. Resistance of sweet potato to bacterial root and stem rot caused by Erwinia chrysanthemi. Plant Dis. 73:984-987.
Corey, K. A., Collins, W. W., and Pharr, D. M. 1982. Effect of duration of soil saturation on ethanol concentration and storage loss of sweetpotato roots. J. Am. Soc. Hortic. Sci. 107:195-198.

Duarte, V., and Clark, C. A. 1992. Presence on sweetpotato through the growing season of Erwinia chrysanthemi, cause of stem and root rot. Plant Dis. 76: $67-71$

Edmunds, B., Boyette, M., Clark, C., Ferrin, D., Smith, T., and Holmes, G. 2008 Postharvest handling of sweetpotatoes. N. C. Ext. Serv. Bull. AG-413-10-B.

Edmunds, B. A., and Holmes, G. J. 2009. Evaluation of alternative decay control products for control of postharvest Rhizopus soft rot of sweetpotatoes. Online publication. Plant Health Prog. 10.1094/PHP-2009-0206-01-RS.

FAO. 2014. FAOSTAT Statistics Database. Online publication. http://faostat3.fao. org/browse/Q/QI/E

Hardy, D. H., Tucker, M. R., and Stokes, C. E. 2008. Crop fertilization based on North Carolina soil tests. N. C. Dep. Agric. \& Cons. Serv., Raleigh, NC, Circ. No. 1 .

Harrison, H. F., Jr., Peterson, J. K., Clark, C. A., and Snook, M. E. 2001 Sweetpotato periderm components inhibit in vitro growth of root rotting fungi. HortScience 36:927-930.

Harrison, H. F., Peterson, J. K., and Snook, M. E. 2006. Simulated drought induces high caffeic acid contents in storage root periderm of greenhouse grown sweetpotatoes. HortScience 41:277-278.

Harrison, H. F., Jr., Snook, M. E., and Peterson, J. K. 2008. Effects of environment and genotypes on the storage root periderm resin glycoside content in sweet potato. Allelopathy J. 22:93-100.

Holmes, G. J., and Stange, R. R. 2002. Influence of wound type and storage duration on susceptibility of sweetpotatoes to Rhizopus soft rot. Plant Dis. 86:345-348.

Kushman, L. J., and Deonier, M. T. 1958. Effects of weather, date of harvest, and curing treatments on keeping qualities of Porto Rico sweetpotatoes. Proc. Am. Soc. Hortic. Sci. 71:369-375

Kushman, L. J., Deonier, M. T., Lutz, J. M., and Bolton, W. 1954. Effects of temperature and soil moisture at harvest and of delay in curing on keeping quality of Porto Rico sweet potatoes. Proc. Am. Soc. Hortic. Sci. 63:415-419.

Lauritzen, J. I. 1935. Factors affecting infection and decay of sweetpotatoes by certain storage rot fungi. J. Agric. Res. 50:285-329.

Mehlich, A. 1984. Mehlich-3 soil test extractant: A modification of Mehlich-2 extractant. Commun. Soil Sci. Plant Anal. 15:1409-1416.

Muhanna, M., and Rees, D. 2004. The role of root sugar content on the susceptibility of sweetpotato cultivars to soft rot. Afr. Crop Sci. J. 12:305-309.

Perkins, D. D. 1962. Preservation of Neurospora stock cultures with anhydrous silica gel. Can. J. Microbiol. 8:591-594.

Ristaino, J. B., and Averre, C. W. 1992. Effects of irrigation, sulfur, and fumigation on Streptomyces soil rot and yield components in sweetpotato. Plant Dis. 82: 670-676.

Rolston, L. H., Clark, C. A., Cannon, J. M., Randle, W. M., Riley, E. G., Wilson, P W., and Robbins, M. L. 1987. Beauregard sweet potato. HortScience 22: $1338-1339$

Schaad, N. W., and Brenner, D. 1977. A bacterial wilt and root rot of sweet potato caused by Erwinia chrysanthemi. Phytopathology 67:302-308.

Srivastava, D. N., and Walker, J. C. 1959. Mechanisms of infection of sweet potato roots by Rhizopus stolonifer. Phytopathology 49:400-406.

Thompson, P. G., Smittle, D. A., and Hall, M. R. 1992. Relationship of sweetpotato yield and quality to amount of irrigation. HortScience 27:23-26.

Ton, C. S., and Hernandez, T. P. 1978. Wet soil stress effects on sweet potatoes. J. Am. Soc. Hortic. Sci. 103:600-603.

United States Department of Agriculture. 2014. Crop production annual summary. National Agriculture Statistics Service. Online publication. http://usda.mannlib. cornell.edu/MannUsda/viewDocumentInfo.do?documentID=1047

Villavicencio, L. E., Blankenship, S. M., Yencho, G. C., Thomas, J. F., and Raper, C. D. 2007. Temperature effect on skin adhesion, cell wall enzyme activity, lignin content, anthocyanins, growth parameters, and periderm histochemistry of sweetpotato. J. Am. Soc. Hortic. Sci. 132:729-738.

Villordon, A., Clark, C., Ferrin, D., and LaBonte, D. 2009. Using growing degree days, agrometeorological variables, linear regression, and data mining methods to help improve prediction of sweetpotato harvest date in Louisiana. HortTechnology 19:133-144. 